УДК 94(477)(092):930(091) Гирич І. Львівська історична школа М. Грушевського

DOI: 10.24919/2519-058x.7.131217

Ihor HYRYCH,

Ph D hab. (History), Head of Department of Source Studies of Modern History of Ukraine of the Institute of Ukrainian Historiography (Ukraine, Kyiv) ihor_hyrych@ukr.net

Ігор ГИРИЧ, доктор історичних наук, завідувач відділу джерелознавства нової історії Украӥни Інституту української археографії та джерелознавства (Україна, Київ) ihor_hyrych@ukr.net

\title{
MYKHAILO HRUSHEVSKYI LVIV HISTORICAL SCHOOL: A NEW HISTORIOGRAPHIC SYNTHESIS
}

\author{
Review of: \\ Vitalii Telvak, Vasyl Pedych. \\ Lvivska istorychna shkola Mykhaila Hrushevskoho. Lviv: Svit, 2016. 440 s.

\section{ЛЬВІВСЬКА ІСТОРИЧНА ШКОЛА МИХАЙЛА ГРУШЕВСЬКОГО: НОВИЙ ІСТОРІОГРАФІЧНИЙ СИНТЕЗ}

\author{
Рецензія на: \\ Віталій Тельвак, Василь Педич. Львівська історична школа \\ Михайла Грушевського. Львів: Світ, 2016. 440 с.
}

The work about Lviv historical school of Mykhailo Hrushevskyi is written by two renowned scholars with a solid scientific experience. In 1996 Vasyl Pedych defended his thesis on this topic in IUASC. Vitaliy Telvak, being occupied with this issue for many years, has been collecting materials about Hrushevkyi's disciples, who, in their turn, avoided the most considerable amount of reviews on the works of their teacher. The scholar assembled the evaluations of the historiographical heritage of the greatest Ukrainian historian of the XX century. Some of them have already been published in Additional series of the 50-volume «Works» of M. Hrushevskyi. Undoubtedly, V. Telvak and V. Pedych appear to be resplendent authors for investigating the issue of Hrushevskyi's historical school.

Vasyl Pedych is less active as the author of original works. On the contrary, Vitaliy Telvak is one of the most productive authors in the sphere of Hrushevskyi studies, an authority in the field of research of the scholar's biography, an author of twelve books about the historian. He is an expert in the realm of investigation of the way Hrushevskyi's works are perceived in the Ukrainian and world's historiography. However, V. Telvak has recently been mainly writing biographical outlines about M. Hrushevskyi's activity. Notwithstanding that, this work is a research study, investigating one of the chief problems of Hrushevskyi studies, what is Lviv school of M. Hrushevskyi, what is the content of his disciples' works. In my view, this monograph is one of the most valuable works of these historians from the point of originality and achieving new results. 
The book consists of three chapters: 1) a review of historiography and sources, 2) Lviv Historic school of M. Hrushevskyi as a scholarly community and sociocultural phenomenon, 3) the Ukrainian past in M. Hrushevskyi's disciples' researches. Considering the interests and previous scholarly works, it may be deduced that the first two chapters were written by V. Telvak and the last one by V. Pedych. An appendix contains valuable archeographic publications - evaluations of theses of M. Hrushevskyi's disciples, written by M. Hrushevskyi, Ludvic Finkl and Bronislav Dembinsky. The authors found these texts in the State archive of Lviv region in the fund of Lviv University among records where protocols about passing doctoral exams with conclusions of scientific advisers and opponents about doctoral candidates were stored. Non-printed archive materials representing unknown before special works of Mykhailo Hrushevskyi that were not published in 50 volumes of «M. Hrushevskyi. Works», were introduced for scientific usage. Biographemes of M. Hrushevskyi's disciples as well as photos of all known up until now representatives of this schools are a valuable contribution too. Some of these photos are printed for the first time. For instance, it has been unknown how Vasyl Herasymchuk looked like so far.

The reviewed book is based on rich unknown or little-known archival documents and on an extremely wide range of publications. The authors raised all the $\mathrm{n}$ and half-forgotten memories, diaries and epistolary sources of Hrushevskyi and his students. The greatest achievement was the elaboration of Lviv University Archives of History and Philosophy Faculties, where researchers have investigated a case concerning Hrushevskyi's scholarly seminar, namely «Historical exercises». The lists of all the students who attended the seminar have been thoroughly investigated, which assumes a high degree of accuracy in defining the number of people whom Hrushevskyi instructed during his 20 years of work in Lviv University. It is worth admiring, that the authors managed to «rise» above sources, demonstrated a fluent command of the topic, which is possible only with a deep immersion in the investigation of source documents, archives, acquiring certain source-erudition. Researchers communicate with the reader not only through narrating a certain source, but they fluently operate with sources, juxtapose contradictory facts, consider all the «pros» and «cons» expressed in the sources often representing the opposing views. They managed to pull away from the main character of the research, resisted to the temptation to support a side of a source that shows only Hrushevky's or a student's rightness. The study of V. Telvak and V. Pedych appeared to be stereoscopic, multifaceted, free of schematization and simplification, as the authors have not concealed any «unfavorable» source that does not fit in a predetermined concept. Because of that, their book is read with great interest and the conclusions are persuasive and trustworthy.

As V. Telvak have correctly stated, to establish a complete list of school members in Lviv period of Hrushevskyi's activity, there should be given the word to his disciples - there should be an evidence that disciples recognize Hrushevskyi as their teacher. For this purpose there was raised all the rich epistolary material, letters of students to Hrushevskyi, and their correspondence with each other, all the available epistolary material from the archives of Kyiv and Lviv. The source base of the investigation is made up of documents of the Central State Historical Archive of Ukraine in Kyiv fund №1235, funds of Shevchenko Scientific Society in Lviv, personal archive of Central State Historical Archives in Lviv and Manuscript section of V. Stefanyk library plus additional documents as diaries and memoirs.

The first researchers who investigated the issue of Lviv school were the disciples of the school themselves, especially Myron Korduba and Ivan Krypjakevych. They were the first 
to declare the existence of such scientific formation of history scholars. It was mentioned by main historiographers of Ukraine, authors of Ukraine's and world's history textbooks Dmytro Doroshenko, Boris Krupnytskyi, Natalia Vasilenko-Polonska, Dmitry Bahaliy, Olexander Ohloblyn. Vitaly Telvak justly notes that the second stage of the research of this sholarly phenomenon is marked by achievements of one of the greatest scholars and founder of Hrushevskyi studies - Ljubomyr Vynar. Moreover, if the historians of the 1920s 1950s distributed M. Hrushevskyi and his students into different historiosophical areas: S. Tomashivsky, M. Koduba, I. Krypjakevych, I. Krevetsky - were assigned to the state (derzhavnytska) school and their teacher was assigned to the preliminary stage - populist (narodnytsky) historiography, L.Vynar was the first to declare that there is no apparent antagonism between Hrushevskyi and state historians, on the contrary he demonstrated historiosophical genetic relationship between teacher and his disciples.

Vitaly Telvak logically opposes Lubomyr Vynar to Omelian Pritsak and his famous article for the 100th anniversary of the historian in 1966 in the journal «Letters to friends». Referring to the opinion of the remarkable contemporary historian Oleksander Yas, V. Telvak considers this article a continuation of the controversy between «populists» and «state historians» in the embodiment of personal discussion of L. Vynar and O. Pritsak. In my opinion the issue is a bit more complicated, as it was mentioned in the article of the journal «Modern Ukraine». The opinion of O. Pritsak seemed to be a strange anachronism, rehearsing old patterns of state historians of early 1920s, when the Hetman ideology of Pavlo Skoropadsky and USHD in which state school acted as the ideological core arose. The paradoxical situation evolved: historians who belonged to the state school were taught by a person who did not have any state aspirations being a federalist. Unfortunately, this aspect of the relationship between Hrushevskyi and his disciples is not represented in the book that thoroughly. However, one book cannot cover all the aspects concerning Lviv historical school of Hrushevskyi. An interesting fact is that later O. Pritsak himself seemed to be a bit embarrassed by this article written 30 years ago. At least in private conversation with the author of the review, he did not answer affirmatively whether he continued to believe that Hrushevskyi contributed to the destruction of Ukrainian aristocracy at the times of Ukrainian revolution.

The third stage of Hrushevky's school research in 1890 - 1914 Vitaliy Telvak naturally assigns to the modern era of Ukrainian independence. In the 1990s - 2000s while exploring the works and activity of Hrushevskyi, the scholars began to investigate the activity of his disciples. The authors of the book mention a range of books and articles about Hrushevskyi's students. In particular, V.Pryshlyak from Lutsk published more than a dozen of publications about one of the representatives of the school - Ivan Dzhydzhora. Ya. Fedoruk wrote about V. Herasymchuk, the former head of the Shevchenko Scientific Society. Oleg Kupchinsky made a research about M. Korduba, I. Krypjakevych was in the focus of study for I. Zabolotna, R. Kryp'yakevych, Ya. Dashkevych and others. V. Telvak cited a long list of bibliography of the issue. However, despite the existence of a number of outstanding research works a major problem remained - what is the Lviv historical school of Mykhailo Hrushevskyi, who are to be considered its members, what are the scholarly peculiarities of the school formation, what are the main criteria of defining who can be considered the member of the school?

The sufficient and persuasive answer is given in the second chapter of the book. This chapter is divided into five parts: 1) The formation, structure and functioning of the school, 
2) members of the school, 3) communicative nature and psychological climate, 4) students and teachers during the war and postwar period, 5) teacher assessed by students. In my opinion, the part about «the staff» in the second chapter is the most valuable part of the study, which also provides an answer to all the previously mentioned issues. There are many criteria to determine the parameters of the scientific school. V. Telvak has chosen Hrushevskyi's seminar in Lviv as the main one. He believes that the school of our most renowned historian is determined by three elements: 1) seminar «Historical exercises», 2) the fact of being the member of the corporation of professional scientists, and 3) a representative of the school had to write at least one independent work (those who wrote only reviews were not included). Definitely there should be included the fourth criterion - a student had to consider himself the representative of Hrushevky's school and be recognized as such by his teacher.

The authors of the monograph referred to the definition of school by L. Vynar, according to which the school should consist of several components: 1) organizational structure - scientific and educational institutions and research centers, 2) common historiographical concepts shared by teacher and students, 3) common research methodology, 4) common historiosophical base, 5) the existence of a common periodical (journal), 5) specific problems of historical research. Paragraphs two, three and four are sufficiently close and connected. They can cover the scholar structure of the group, which was Hrushevky's seminar in Lviv University. O. Yas in his turn distinguishes school only by three main components: 1) common intellectual (conceptual) models, 2) education and educational components (seminars, lectures, regular forums), 3) technical and organizational component (periodicals). O. Yas considers a certain research program to be a necessary feature of school. Institutionalizational consciousness of the scientific community, according to O. Yas, required the functioning of two important things: 1) the circulation of ideas or concepts that define the orientation of the educational process and 2) personal communication among scientists within the school.

The need to represent the vertical connection between historians called to life two important terms - the course and the movement. According to O. Yas, the movements are distinguished by historiosophic ideas (populist (narodnyky), state (derzhavnyky), neopopulist (neoderzhavnyky) etc.), the paradigms of scientific thinking (rationalistic, Enlightenment, romantic, positivistic etc.), political or ideological entity (royalist, republican, conservative, liberal, Marxist). There are other variations of structural separation. As far as I am concerned, the first and third factors are interrelated in the case of Ukrainian historiography. Thus, the historians of the state school linked republican ideology to populist historical trend. The same state course they correlated with the type of conservative thinking and interpretation of history. In such a way, the state historiography became the ideological foundation of the Hetman's ideology. It is important to keep in mind the fact that the most remarkable students were assigned to the state school. So it turns out that the school of Hrushevky actually represents two opposing camps, but are they opposite indeed?

On the other hand, we have another example where among V. Antonovych's students there were okremishnyky (people who recognized the distinctiveness of Ukrainian culture) M. Hrushevskyi, V. Domanytsky, brothers Volodymyr and D. Scherbakivsky, and at the same time - Russian centralists - velykoderzhavnyky (those who declared the restoration of a great country) I. Lynnychenko, A. Storozhenko, F. Nikolaychyk. In a narrow sense, all these people are members of one documentalist school of Volody- 
myr Antonovich, on the other hand, they are representing two opposite historiographical or rather conceptual (historiosophical) movements. In terms of thematic focus I. Lynnychenko and A. Storozhenko may be assigned to the school of V. Antonovych as representatives of study of Ukraine-Rus and Cossack history of XVI-XVII centuries. But in terms of the leading historiosophical course these historians can not be considered as students of the Kiev school of V.Antonovych, although they were disciples of the latter.

$\mathrm{V}$. Telvak justly states that unlike V.Antonovych' school, students of whom were representing the Russian historiography as they denied the Ukrainian historical process, all the students of Hrushevky were conscious political Ukrainians. Therefore, these schools should not be defined as similar, mixed in one as offered by O. Dombrovskyi - the school of V. Antonovych and M. Hrushevskyi. In terms of leading creative ideas, ideological courses, there is a distance, if not a gap, between V. Antonovych and M. Hrushevskyii.

There is still popular Ivan Krypiakevych's statement that the author of «History of Ukraine-Rus» had about a hundred students. Historians have interpreted this expression literally and it became an axiom for the issue of the number of representatives of the Lviv historical school. V.Telvak declared that it is not a large number of mythical representatives of the school, but their real presence. Not all students, i.e. those who attended lectures of Hrushevky were professional historians and only professional historians should be considered the members Lviv school of historians. Professionalism is a relative thing. Professionals are not only those who work in the sphere of higher education and write scientific papers, but also those who declared their professionalism by some publications, and then moved to another field of activity. Typically, most of Hrushevskyi's students worked as teachers in Grammar schools and did not show themselves as historians. Such teachers were not included to the school by V. Telvak.

Basing on the premise of his governing criterion, Vitaliy Telvak lists 22 students of Hrushevskyi Lviv Historical School. Hrushevskyi himself names 15 people in his «Autobiography», dated by 1906: O. Terletsky, D. Korenets, M. Korduba, S. Tomashivsky, S. Rudnytsky, O. Tselevych, Yu.Kmit, Z. Kuzelya, O. Chaykivsky, V. Herasymchuk, O. Sushko, F. Holiychuk, I. Dzhydzhora, I. Krevetsky, I. Krypiakevych. V. Telvak adds seven more people to the 15 above mentioned: B. Barvinsky, I. Shpytkovsky, M. Zaliznyak, B. Buchynsky, F. Sribny, M. Bordun, M. Stadnyk. A small essay about each of them including biographical and artistic characteristics is given in the book. V. Telvak describes the time of seminar studies, scientific merits, the election as the full members of the Archaeological Commission of the Shevchenko Scientific Society or as the ordinary and active members of the Shevchenko Scientific Society. He also tried to file collective prosopographic portrait of the representatives of the school: their social status, age, thematic areas of their experiments.

Not all the members of M. Hrushevskyi school were historians. S. Rudnytskyy started as a historian, but later became a geographer, one of the founders of the national geography. Zenon Kuzelia put himself on record in the history of science as an outstanding ethnographer. Mykola Zaliznyak became a politician and political scientist after the seminar studies, investigated the political structure of the countries of the world that used federal model of the state. Inclusion of M. Zaliznyak into M. Hrushevskyi school is one of the achievements of V. Telvak and V. Pedych research. Mykola Stadnyk investigated Hadiach agreement but left the field of history and then studied in Krakow as a lawyer. Yu. Kmit did not study in 
Lviv University at all. He was the student of the seminary, but passed a historical seminar of M. Hrushevskyi and therefore, was logically included in the school of Lviv professor by V. Telvak. Oleksandr Sushko at first studied at K.Studynsky, literary critic, and can be considered a mutual student. B. Barvinsky defended his doctorate under the authority of L. Finkl but was close to M. Hrushevskyi by his conceptual approaches. Melania Bordun was the only female student in the school. V. Telvak did not include Mykola Chubaty in M. Hrushevskyi School, because he only attended lectures and did not pass the seminar training, and defended the doctorate after the World War I, when M. Hrushevskyi was not in Lviv. As for me, this argument is not entirely convincing. In fact, if to consider the methodological principles and conceptual approaches, M.Chubaty ticks all the boxes for M. Hrushevskyi School.

Several M. Hrushevskyi's students were not included to the school. Yevhen Barvinsky really turned to Polish historiography, lost historiosophical communication with the school of the author of «History of Ukraine-Rus», and worked for the Polish historiography. The objection to his including in the school looks quite reasonable. I. Flunt and Y. Forostyna attended the seminar, prepared to defend their doctorate, but did not create their original works, thus V. Telvak did not include them to M. Hrushevskyi's school.

Including the lists of all students or individuals who attended the seminar into the book would be an obvious thing. Also, it would be interesting to have a list of Lviv University students who listened to M. Hrushevskyi's lectures. Among them we could find a people who did not write highbrow scientific papers, but could have become the authors of popular books, articles in the press, etc. In this way, we could create a circle of students of the second order who did not become historians and researchers, though they were the mentors of young representatives of Ukrainian intelligentsia in Galicia, and therefore the public figures that influenced the cultural life of Western Ukraine.

By putting the criterion of belonging to Hrushevskyi's school - studying at the undergraduate seminar, V.Telvak exhaustively and consistently transferred it to the sphere of life, listed all the people who, under this definition, belong to the school of Lviv professor. This is one of the greatest achievements of reviewed publication.

On the other hand, whether it is right to assume the criterion of seminarium as the only possible one? Should we include only historians to Hrushevskyi's school? In my opinion, it is worth involving researchers that belonged to related disciplines: publicists, literary scholars, political and social scientists. These related experts were historians at the same time - the authors of a number of valuable works that often exceed quantity of works of the people who have passed «historical exercises» of Lviv professor. As for me, we have no right to reject the second criterion of belonging to the school - work in journals, edited by M. Hrushevskyi, such as «Memoirs of the Shevchenko Scientific Society», «Literary and Scientific Journal», «Publishing Union» and other special collections of the Society. They were the school no less than the seminar. These publications were also a scientific training, tantamount to the seminar. Moreover, some of these Hrushevskyi's employees belonged to his «Familia» - close collaborators of the historian.

V. Telvak agrees with the definition of S.Pankova concerning the existence of Hrushevskyi's journalistic school. Therefore, in my view, we should also look broader at the representation of Hrushevskyi's school in Lviv. Moreover, there were only 18 people doing only practices on history, from 22 representatives of school listed by Drohobych historian. 
Volodymyr Hnatiuk was one of Hrushevskyi's students at the faculty, the latter graduated from Lviv University during the years of active teaching work of Hrushevskyi. I believe that when we include Z. Kuzelya, an ethnographer, into students, then we should have included V. Hnatiuk as well. V.Hnatiuk was only a year older than Yu. Kmit' and four - than Stepan Tomaszewski. Hrushevskyi was one of the founders of the national school of Ukrainian ethnography, and had an impact on V.Hnatiuk, regarding his ethnographic activity.

In my opinion, we can include Mykhailo Wozniak to the disciples of Hrushevskyi with some justification. Not only did he attend Hrushevskyi's lectures at the University, but what is most important, he was actively published in «Memoirs of the Shevchenko Scientific Society» and in the 1920s performed the orders of the academician on the research of links of unity concerning Galicia with the Great Ukraine. Vozniak's publications entirely fit into M. Hrushevskyi's interpretation of the nineteenth century in the context of conceptuality, and that is the main thing for us. Hrushevskyi also considered his disciple, prominent literary critic. Works of M. Yevshan as a critic fit into the context of literary interests of Hrushevskyi. In his writings, M. Yevshan uses historical and literary method, while being a historian of culture. Hrushevskyi not only ordered the articles to M. Yevshan, but also discussed the conceptual aspects in the assessment of Ukrainian literary process of early twentieth century. Mykola Hrushevskyi compares Mykola Yevshan to Ivan Dzhydzhora by his value and closeness to himself.

As far as I am concerned, we should not forget about the representatives of the young «Familia» of Hrushevskyi that signed his answer «In defense of truth» to the libelous brochure of S. Tomashivsky «Before the General Meeting of the Shevchenko Scientific Society», dated by 1913. We are talking about Osyp Rozdolsky and Mykhailo Mochulsky. The latter was, moreover, a distant cousin-in-law of Hrushevskyi. There is no escaping from the fact of the impact of Hrushevskyi's concepts of the social New Age in Ukraine on his studies of historical and literary life of the nineteenth century. Mykhailo Lozynskyi, journalist and social scientist, is famous for very fruitful work in the journals of Hrushevskyi. He himself gave place in the library of the Shevchenko Scientific Society to bibliographer Volodymyr Doroshenko and cooperated with him actively. Furthermore, Doroshenko was a prominent historian of the political movement of the XIX - early XX century that was the object of Hrushevskyi's studies at the time.

The second chapter of the book - «The communicative nature and psychological climate [of Hrushevskyi school]» tends to be yet another most important chapter from the point of scientific findings, that solves many controversial issues of Hrushevskyi studies. V. Telvak managed to describe the relationship between the mentor and his students in a sensitive and tactful manner, not to come down on the side of any party during mentioning the inevitable conflicts that took place between M. Hrushevskyi and his environment, to cover all the complexities of the personal relationship, and even perspective of their time genesis, as objectively as possible. The false stereotype of «exploitation of the students» by professor has been discarded in the work. Another trend has been highlighted instead; the professor took care of material condition of his students, was concerned about their employment and gave them a start in the independent scientific life. It was very difficult to implement all of it in the conditions of colonial reality of Western Ukraine, as it was necessary for Hrushevskyi to find the additional sources of financing, and sometimes to give his own money. V. Telvak 
gives an interesting list of appeals of students to the mentor and vice versa, that indicates the relationships based on positivity and trust in the team ipso facto. All the students were friendly to each other to different extents. They had active epistolary contact with each other, which would have been impossible if the historical school of Hrushevskyi would have been just a usual formality, if all the students would not have been united by the joint public and cultural ideals.

In this chapter, V. Telvak emphasizes on the fact that the relationship between the mentor and the representatives of his school may quite fit in the generally known communicative issue of conflict called «Fathers and Sons». «Sons» continue the father's work, go further by growing up from the «short pants» of the «half-baked» scientists, thus being involved in the building of their own models of historiographical process. The fact that during the conflict in 1913 almost all the students were on the side of the opposition or held a neutral position, thus just a few of them supported Hrushevskyi, tends to be an evidence to it.

The book shows how S. Tomashivskyy, a person that spared no effort to support the expansion of public popularity of Hrushevskyi to 1905, begins to confront the teacher from 1906, and in the 1911 - 1913 becomes a major oppositionist to Lviv Professor in the middle of the Shevchenko Scientific Society, the author of some anonymous lampoons on its political, scientific and organizational activities in Lviv. V.Telvak considers the personal reasons to be the catalyst of this sudden change in the relationship. I think that the reason there consisted also in the other conceptual vision of the political development of Ukraine. Communalism theory of Hrushevskyi included the domination of the interests of Great Ukraine, as the main part of the all-Ukrainian territory, above the Galicia - as the mandatory element. At the beginning of his scientific career, Stepan Teodorovich shared these thoughts of mentor. Once getting into the governing nucleus of the National Democratic Party, S. Tomashivsky begins to consider Galicia as the flagship of Ukrainian liberation movement, and the «Russian» Ukraine - only as a reservoir of personnel, as an auxiliary link in this process. S. Tomashivskyy was a consistent supporter of the compromising policy concerning the governing political circles of Poland. He failed to win Hrushevskyi over, so he began a consistent fight against Hrushevskyi's concept of the Ukraine's past and his political action on the eve of the First World War. However, he was doing this in quite an unsympathetic and immoral way of anonymous mischief-making, distortions of facts, slandering. It is interesting that in the times of war M.Korduba took the part of Hrushevskyi concerning his political strategy on the eve of the revolution and declared the vision of S.Tomashivsky as the false one. Because of the conceptual views of historians of Hrushevskyi's school, M. Korduba's letters to his mentor, dated by the 1910s, in which he criticized S.Tomashivsky for an insufficient attention to the state-building moments in Ukrainian history during the period of the Cossack state, are considered interesting.

I. Krypiakevych has been the closest one to S. Tomashivsky from all the students of Hrushevskyi, and it has been rightly observed by V. Telvak. An extensive correspondence between them, mainly from the 1920s, has been preserved. Both were the co-founders of the statist vision of Ukrainian history, both had chilled relationship with M. Hrushevskyi in the mid-1910s to the early 1920s. But it was Mykhailo Serhiyovych who has made the first steps towards reconciliation after returning to Kyiv in 1924 by bringing all his disciples except for S.Tomashivsky, I.Krevetsky, and some others, in the work in the structures of the historical section of UAS. 
$\mathrm{V}$. Telvak describes the picture of the formation of relationships with each student in detail, and they were very different. Ironically, despite the incredibly hostile relations of Hrushevskyi with O.Barvinsky, the son of the latter - Bogdan Barvinsky - was among the students of Lviv professor. A number of works of this talented young scientist was written under the leadership of Hrushevskyi. So, Hrushevskyi could rise above the level of personal relationships. For that matter, it is hard to miss the conceptual continuity with thoughts of Mykhailo Hrushevskyi in Barvinsky's book «Historical Development of the Name of Ukrainian-Rus People», written after the diffidation of the mentor and the student in 1908.

Oleksandr Sushko has spoiled the relations with M. Hrushevskyi very soon by spreading false rumors about the trip of I. Franko and Lviv professor to Rome in carriages of different classes. Due to the cooling of relations O. Sushko passed his doctoral exams with Polish professors, and not with Hrushevskyi. Stepan Rudnytsky, who was a distant relative of S. Dnistryansky and one of the main antagonists of Hrushevskyi, was a member of various oppositions in the Shevchenko Scientific Society.

Those were Hrushevskyi's students, especially I. Krypiakevych, M. Korduba and V.Herasymchuk, who wrote the most fundamental evaluation of scientific heritage of Hrushevskyi, concerning the contribution of his «History of Ukraine-Rus» to the treasury of Ukrainian and world historiography. The chapters «The students and mentor during the war and post-war period» and «Mentor in the assessments of students» mention about it as well as about the relationship of the academician with students in the 1920-1930s.

The third chapter «Ukrainian pastimes in the studies of Hrushevskyi's students», written by Vasyl Pedych, has been dedicated to the historiographical problems of works of representatives of Hrushevskyi Lviv Historical school. He has withdrawn from the tradition concerning the individual description of each student's heritage and combined all the students in thematic clusters by areas of their studies' activity. As a result, V. Pedych has identified seven thematic clusters: the Princely era and the Lithuanian-Polish period, Ukrainian Cossackdom to the middle of XVII century, Khmelnychchyna, the Ruin, Mazepa Hetmanate and the times after it, and Koliyivshchyna, which together make up the era of Cossackdom and Galician history of the XIX century.

This section is the first attempt to describe the historiographical contribution of each Hrushevskyi's student by chronological and thematic principle in our historiography. The attempt is successful as a whole, as it will be useful not only for researchers, but also can successfully be used for the educational process in the universities of Ukraine. The period of the rise of Kyiv Rus state to the days of Ivan Mazepa has been the most prolific for the experiment. S. Tomashivsky, M. Korduba and I. Krypiakevych were primarily synthetic historians and analysts at the same time in all these periods. It is no coincidence that we consider them the most talented students of Hrushevskyi. All of them have written about the princely UkraineRus, while being insightful researchers of Khmelnychchyna. M.Korduba specialized in international politics and diplomatic history, S. Tomashivsky - on the popular movements in Galicia; I.Krypyakevych investigated the internal structure of the state of B. Khmelnitsky, and in times of Hrushevskyi's life in Lviv - the issue of urban population of Lviv (Ukrainian presence) of the XVI century. The rest of the historians have shown themselves in specific thematic niches: F. Sribny studied Stauropegial brotherhood in Lviv, I. Shpytkovsky - Koliyivshchyna, I. Dzhydzhora - trade of Hetmanshchyna during the times of Danylo Apostol 
at the beginning of the XVIII century, V.Herasymchuk - the times of Ruin, hetmanship of Ivan Vyhovsky and Hadiach treatise, M.Stadnyk - Hadiach treatise, D.Korenets - Martyn Pushkar rebellion (as well as times of Vyhovsky), O. Sushko - the Union of the middle of the XV century, B. Barvinsky - Grand Duchy of Lithuania of the XIV - XV centuries, B. Buchynsky - the Union of the XVI century. I. Krevetsky, who specialized in Ukrainian public life in the times of European revolutions in 1848 and Yu. Kmit, who was interested in the religious life of the mid-nineteenth century, based their studies on the history of the nineteenth century. We cannot mention of all students and subjects here. A church history, on which O. Sushko, B. Buchynsky, M. Bordun, Yu. Kmit worked, is a group of great interest that deserves a separate mentioning.

There is hardly a topic that can be completely covered by only one study, but the research of V. Telvak and V. Pedych is related to the editions, after the publication of which any subsequent researcher dealing with the problems of Hrushevskyi Lviv historical school will be unable to pass by it without having a look at the findings and evaluation of the two authoritative scholars. The benefits of the work should include such a moment: its content is much richer than the issue indicated on the cover of it. In a broader sense, this is a story of socio-cultural and scientific life of Galicia in the late XIX - early XX century. The image of Hrushevskyi Lviv historical school has been masterfully inscribed in the broader context of social life in Galicia, Polish-Ukrainian relations, contacts with Naddnipryanshchyna (the Dniper Ukraine) on the issues of unity, and the like. In my opinion, this work is one of the best books in the field of Hrushevskyi studies for the last 10-15 years.

Стаття надійшла до редакиії 02.03.2018 р. 